\title{
Study on Growth Parameters of Potato by Using Biocontrol Agent Pseudomonas Fluorscens with NPK
}

\author{
Nidhi Lal \\ Department of Botany, St. Andrew's College, Gorakhpur \\ *Corresponding Author: Nidhi Lal, Department of Botany, St. Andrew's College, Gorakhpur

\begin{abstract}
An attempt was made to study the bio-control efficacy of Pseudomonas Fluorscens on growth parameter of potato crop. Three type of treatment soil treatment, seed treatment and foliar treatment in combination with farm yard manure were given. The result was recorded at sixty days after sowing and ninety days after sowing and at the time of harvest. The best result was recorded in soil treatment followed by foliar treatment and seed treatment in comparison with control. Therefore from present investigation it is concluded that an eco-friendly biopesticide Pseudomonas Fluorscens is very easy to use and having no adverse effect on crops, people or animals and they can be applied to prevent and control several pathogenic fungi and grow healthy crop. The Pseudomonas Fluorscens can be used as a bio-control agent as it is low cost and profitable dependent system and it also helps in conserving the natural resource.
\end{abstract}

Keywords: Pseudomonas Fluorscens, soil treatment, foliar treatment, seed treatment, pathogenic, fungibiocontrol, effect on growth parameter.

\section{INTRODUCTION}

India is fortunate enough to have vast diversity of land soil and agro climatic condition to grow various vegetable. Potato is the one of the most starchy food crops of the world. Today farmer are searching for resource efficient low cost and profitable dependent system, chemical pesticides when especially used indiscriminately have contaminated the environment. A number of plant diseases especially the soil and seed born could not be significantly controlled by chemical means and gain the resistance from the chemicals. So the substitute is only to apply cultural and biological practices, biological control methods are alternative means of disease control and grow healthy crop, which are the otherwise unprotected because of the involved expenses. An ecofriendly biopestcides viz. Pseudomonas Fluorscens product is very easy to use and having no adverse effects on environment (crop, people or animals). They can be applied to prevent and control several pathogenic fungi such as Fuarium, Rhizoctania, Phythium, Phytopthora, Alternaria etc. and grow healthy crop.

\section{MATERIALS AND MethodS}

\subsection{Experimental Site}

The experiment was conducted in the farm of Allahabad Agriculture Institute-deemed university Allahabad during the Rabi season of 2001-2002 and 2002-2003. Immediately after harvest of the kharif crop, the experimental field was ploughed $20-25 \mathrm{~cm}$ deep with soil turning plough. Cross ploughing and one planking was also done to obtain the good tilth fifteen centimeters deep furrows were opened with the help of bullock drawn furrows maker at the appropriate distance. Seed beds were prepared for respective treatment as per the lay out planned plot for each treatment $2 \times 2$ square meters. The seed variety selected for the study was Kufri Bahar. NPK: Nitrogen phosphorus potassium was given@ $@ 30 t /$ ha in selected plot and mixed well with the soil and was broadcasted uniformly in the soil.

\section{TYPES OF APPLICATION}

\subsection{Seed Treatment}

The seeds of potato were treated and then the seeds were spread on an airy and hygiene place. The uniform sized and well sprouted healthy tubers were collected for sowing. 


\subsection{Soil Treatmeant}

Little amount of soil was taken and treated. $15 \mathrm{~cm}$ deep furrows were made with the help of hoe. Treated soil was broadcasted informally in to the furrows. Seeds were placed in the furrows and were later covered with soil.

\subsection{Foliar Spray}

Foliar spray was given by hand sprayer till the leaves became thoroughly wet. This treatment was given 30 days after sowing. This spray was repeated after 15 days of interval till February.

\section{Detail of Treatments}

1- $\mathrm{T}_{1}$ - soil application @ $3 \mathrm{Kg} / \mathrm{ha}+\mathrm{NPK}$

2- $\mathrm{T}_{2}$ - Seed application @ $200 \mathrm{~g} / 500$ tubers+NPK

3- $\mathrm{T}_{3}$ - Foliar application @ 2.5kg/ha+NPK

4- $\mathrm{T}_{0}$ - control

\section{Observation on Plant Growth Parameters}

1. Shoot Length $(\mathrm{cm})$ :- Shoot length was measured from the soil to the upper part of the plant at 60 and 90 DAS with the help of measuring scale.

2. Root Length $(\mathrm{cm})$ :- Root length was measured at 60 and 90 DAS with the help of measuring scale.

3. Fresh and dry shoot weight (gm): Plants were randomly dug with underground plant portion and detached from root and weighed at 60 and 90 DAS. Then the same were dried at $60^{\circ} \mathrm{C}$ for 48 hours and weighted to record the shoot dry weight.

4. Fresh and dry root weight (gm) :- Plants were randomly dug with underground plant portion and detached from shoot and root were weighted at 60 and 90 DAS. The same were dried at $60^{\circ} \mathrm{C}$ for 48 hours and weighted to record the root dry weight.

5. Number and Weight of potato tuber (gm) :- Three plants were randomly dug out and number \& weight of potato tubers were recorded.

6. Potato Yield (q/ha) :- The tuber yield was recorded from each plot separately.

\section{RESUlt}

Effect of Pseudomonas Fluorscens with NPK on growth parameters of potato

\begin{tabular}{|c|c|c|c|c|c|c|c|c|c|c|c|c|c|c|c|}
\hline \multirow{2}{*}{\begin{tabular}{|c|} 
Treatment \\
Time
\end{tabular}} & \multicolumn{2}{|c|}{$\begin{array}{l}\text { Shoot } \\
\text { Length } \\
\text { (cm) }\end{array}$} & \multicolumn{2}{|c|}{$\begin{array}{c}\text { Root } \\
\text { length } \\
(\mathrm{cm})\end{array}$} & \multicolumn{2}{|c|}{$\begin{array}{c}\text { Fresh Shoot } \\
\text { Weight } \\
\text { (g) }\end{array}$} & \multicolumn{2}{|c|}{$\begin{array}{c}\text { Dry Shoot } \\
\text { Weight } \\
\text { (g) }\end{array}$} & \multicolumn{2}{|c|}{$\begin{array}{c}\text { Fresh } \\
\text { Root } \\
\text { Weight } \\
\text { (g) }\end{array}$} & \multicolumn{2}{|c|}{$\begin{array}{c}\text { Dry Root } \\
\text { Weight } \\
\text { (g) }\end{array}$} & \multirow{2}{*}{\begin{tabular}{|c|}
$\begin{array}{c}\text { Number } \\
\text { of potato } \\
\text { tuber } \\
\text { formation }\end{array}$ \\
$\begin{array}{c}\text { At } \\
\text { harvest }\end{array}$
\end{tabular}} & \multirow{2}{*}{ 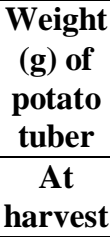 } & \multirow{2}{*}{$\begin{array}{c}\begin{array}{c}\text { Yield } \\
\text { (q/ha) } \\
\text { of } \\
\text { potato }\end{array} \\
\begin{array}{c}\text { At } \\
\text { harvest }\end{array}\end{array}$} \\
\hline & $\begin{array}{c}60 \\
\text { DAS }\end{array}$ & $\begin{array}{c}\text { 90 } \\
\text { DAS }\end{array}$ & $\begin{array}{c}60 \\
\text { DAS }\end{array}$ & $\begin{array}{c}90 \\
\text { DAS }\end{array}$ & $\begin{array}{c}\text { 60 } \\
\text { DAS }\end{array}$ & $\begin{array}{c}90 \\
\text { DAS }\end{array}$ & $\begin{array}{c}\text { 60 } \\
\text { DAS }\end{array}$ & $\begin{array}{c}90 \\
\text { DAS }\end{array}$ & $\begin{array}{c}60 \\
\text { DAS }\end{array}$ & $\begin{array}{c}90 \\
\text { DAS }\end{array}$ & $\begin{array}{c}\text { 60 } \\
\text { DAS }\end{array}$ & $\begin{array}{c}90 \\
\text { DAS }\end{array}$ & & & \\
\hline $\mathbf{T}_{\mathrm{o} \text { Control }}$ & 46.78 & 51.87 & 5.04 & 5.24 & 32.89 & 43.77 & 3.92 & 5.58 & 1.51 & 2.30 & 0.34 & 0.53 & 4.27 & 25.36 & 98.01 \\
\hline $\begin{array}{c}\mathbf{T}_{1 \text { Soil }} \\
\text { P.F.+NPK } \\
\end{array}$ & 75.09 & 89.31 & 9.04 & 9.98 & 75.12 & 92.39 & 8.17 & 10.66 & 3.59 & 4.68 & 0.63 & 1.29 & 7.50 & 40.88 & 244.74 \\
\hline $\begin{array}{l}T_{2} \text { Seed } \\
\text { P.F.+NPK }\end{array}$ & 64.09 & 82.90 & 5.23 & 7.87 & 94.33 & $\mid 184.56$ & 7.86 & 33.92 & 4.94 & 5.48 & 0.75 & 1.07 & 12.67 & 44.19 & 223.61 \\
\hline $\begin{array}{l}T_{3} \text { Foliar } \\
\text { P.F.+NPK }\end{array}$ & 84.71 & 87.47 & 10.09 & 10.70 & 89.38 & 110.96 & 7.96 & 8.47 & 4.34 & 6.14 & 0.55 & 1.79 & 8.67 & 30.00 & 214.43 \\
\hline
\end{tabular}

NPK - Nitrigen Phosphorus Potassium; DAS - Days after sowing; P.F. - Pseudomonas fluorescens

\section{DISCUSSION}

\section{Effect of Pseudomonas Fluorscens with NPK on growth parameter of potato}

The data recorded on growth parameters of Pseudomonas Fluorscens. Treated plot indicated that shoot length, dry shoot weight,, yield of potato were increased in treatment $\mathbf{T}_{\mathbf{1}}$ (NPK+soil P.F.). whereas treatment $\mathbf{T}_{\mathbf{2}}$ (NPK+seed P.F.) increased ,Fresh shoot weight,no.of potato tuberand weight of potato Significant increase in weight of potato in $\mathbf{T}_{\mathbf{3}}$ (NPK+ Folier P.F.). Vrany and Fiker 1984 
reported that P. Fluorescens gave 4-30\% improvement in growth and yield Meena and Gupta (1996) also reported that tuber yield was highest with nitrogen management.

\section{CONCLUSION}

From all the above we can conclude that biocontrol agent when applied in combination with NPK had beneficial effect on potato growth.

\section{REFERENCES}

[1] Vrany, J. and Fiker, A. 1984. Growth and yield of potato plants inoculated with rhizosphere bacteria. Folia-microbiologica .29(3):248-253

[2] Meena, L.R. and Gupta, M.L. 1996. Organic manure and nitrogen management in potato under heavy soils of southern Rajasthan. Journal of the Indian potato Association. 23: (3-4): 166-167.

Citation: Nidhi Lal, "Study on Growth Parameters of Potato by Using Biocontrol Agent Pseudomonas Fluorscens with NPK", International Journal of Research Studies in Biosciences (IJRSB), vol. 6, no. 2, pp. 1-3, 2018. http://dx.doi.org/10.20431/2349-0365.0602001

Copyright: () 2018 Authors. This is an open-access article distributed under the terms of the Creative Commons Attribution License, which permits unrestricted use, distribution, and reproduction in any medium, provided the original author and source are credited. 